\title{
New and poorly known Oriental Alticinae (Coleoptera: Chrysomelidae)
}

\author{
Новые и малоизвестные ориентальные виды Alticinae \\ (Coleoptera: Chrysomelidae)
}

\author{
L.N. Medvedev \\ М.Н. Медведев
}

Institute for Problems of Ecology and Evolution, Russian Academy of Sciences, Leninsky prospect 33, Moscow 119071, Russia. Институт проблем экологии и эволюции РАН, Ленинский проспект 33, Москва 119071, Россия.

KEYWORDS: Chrysomelidae, Alticinae, Oriental region, new species, taxonomical notes.

КЛЮЧЕВЫЕ СЛОВА: Chrysomelidae, Alticinae, Ориентальная область, новые виды.

ABSTRACT. 18 new species are described as new for science: Nonarthra laysi, Epithrix bipunctata, Argopistes borneoensis, Chilocoristes schawalleri, Ch. borneoensis, Amphimela megalayana, A. laosica, A. srilankana, Halticorcus bhutanicus, Phygasoma nigripennis, Laboissierea indica, Hyphasis srilankana, H. pahangi, Hespera gorbunovi, Luperomorpha marginicollis, Ivalia sichuana, I. nilgiriensis, Neocrepidodera javana. Chilocoristes septemmaculatus Chen, 1934 is resurrected from synonymy. Remarks concerning Hyphasis wallacei Baly, 1874 are given.

РЕЗЮМЕ. Описываются 18 новых для науки видов: Nonarthra laysi, Epithrix bipunctata, Argopistes borneoensis, Chilocoristes schawalleri, Ch. borneoensis, Amphimela megalayana, A. laosica, A. srilankana, Halticorcus bhutanicus, Phygasoma nigripennis, Laboissierea indica, Hyphasis srilankana, H. pahangi, Hespera gorbunovi, Luperomorpha marginicollis, Ivalia sichuana, I. nilgiriensis, Neocrepidodera javana. Восстановлен из синонимов Chilocoristes septemmaculatus Chen, 1934. Рассмотрены таксономические проблемы Hyphasis wallacei Baly, 1874.

\section{Introduction}

Alticinae of Oriental region are still very poorly studied. Intensive collecting in these areas during the last years resulted in the descriptions of numerous new species and genera.

The present paper based mostly on materials of author's collection and partly received from the other museums. As a result of this investigation, 18 species are described as new for science, as well as taxonomical notes about a few poorly known species. A key for the genus Phygasoma Jacoby, 1888 is also given.

Acronyms of depositories: NHMB - Naturhistorisches Museum, Basel, Switzerland; SMNS — Staatliches Museum für Naturkunde, Stuttgart, Germany; LM - Collection of L. Medvedev, Moscow, Russia.

\section{Taxonomical part}

Nonarthra laysi L.Medvedev, sp.n.

MATERIAL. Holotype,, : Philippines, N. Luzon, Kalinga Province: Butbut, 3.VII.1988, leg. Pascal Lays (LM).

DESCRIPTION. Fulvous, antennal segments 5-11, oblique band on apical quarter of elytra (Fig. 1) and abdomen except margins black.

Body ovate, 1.6 times as long as wide. Head shining, practically impunctate, frontal tubercles indistinct. Antennae reach anterior quarter of elytra, proportions of segments are as 13-6-7-9-9-9-10-10-13, segment 4 almost cylindrical, more than twice as long as wide, preapical segments about 3 times as long as wide. Prothorax 1.9 times as wide as long, broadest at base, side margins straight, surface shining and very finely punctate. Elytra 1.2 times as long as wide, distinctly rounded on sides, surface shining, very finely, almost indistinctly punctate. Inner margin of hind tibiae slightly serrate in apical half. Length of body $4.5 \mathrm{~mm}$.

DIAGNOSIS. Near N. luzonica L.Medvedev, 1993, differs in color of antennae, head, elytra and underside and less elongate elytra.

Epithrix bipunctata L.Medvedev, sp.n.

MATERIAL. Holotype, $0^{\top}$ : China, Sichuan, $103^{\circ} 20^{\prime} \mathrm{E} / 29^{\circ} 30^{\prime} \mathrm{N}$, Mt. Emei, 500-1200 m, 4-18.V.1999, leg. S. \& L. Kolibac (NHMB). Paratypes: same locality and date, 2 ex. (NHMB, LM).

DESCRIPTION. Fulvous, scutellum, a spot behind middle of elytron (Fig. 2) and underside black, hairs of upperside white.

Head finely punctate, frontal sutures straight, frontal tubercles ovate, distinct, interantennal space narrow, but not ridged. Antennae reach anterior third of elytra, proportions of segments are as 7-3-3-6-7-7-6-6-5-5-7, preapical segments about 4 times as long as wide. Prothorax 1.35 times as wide as long, angulate in anterior quarter, lateral margin behind angulation practically straight, surface with strong and dense punctures, basal groove shallow, delimited with shallow longitudinal grooves, consisting about a quarter of protoracic length. Elytra 1.4 times as long as wide, elytral rows distinct to apex, scutellar row short, interspaces narrow, costate or at least costate. Aedeagus - Fig. 17. Length of male 2.1-2.2 mm, of female $2.6 \mathrm{~mm}$.

DIAGNOSIS. Near E. setosella Fairmaire, 1888, differs with entirely fulvous upperside with dark spot on elytra and cuneiform aedeagus. 
Argopistes borneoensis L.Medvedev, sp.n.

MATERIAL. Holotype, $0^{7}$ : E. Malaysia, Borneo, Sabah, Kinabalu Mt., 06 $00^{\circ} \mathrm{N}, 116^{\circ} 33^{\prime} \mathrm{E}, 1500 \mathrm{~m}, 27-31 . V I I .2009$, leg. O. Gorbunov (LM).

DESCRIPTION. Fulvous, antennal segments 3-10, and spots on elytra: humeral, median and 2 common spots on base and apical slope of suture black (Fig. 3).
Body short ovate, 1.3 times as long as wide. Head impunctate, dull, densely microsculptured, frontal tubercles absent, frons a little narrower than transverse diameter of eye. Antennae rather short, reach humeral tubercle, proportions of segments are as 16-7-5-7-7-7-7-7-7-11, preapical segments as wide as long or slightly transverse. Prothorax 1.4 times as wide as long, broadest at base, strongly narrowed anteriorly, lateral margins feebly

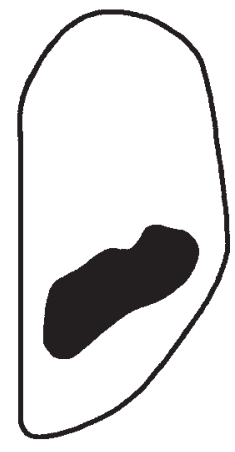

1

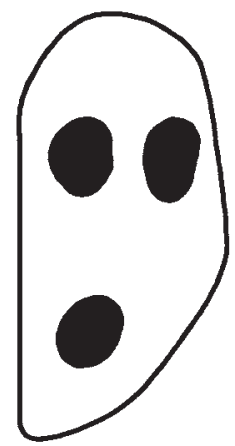

6

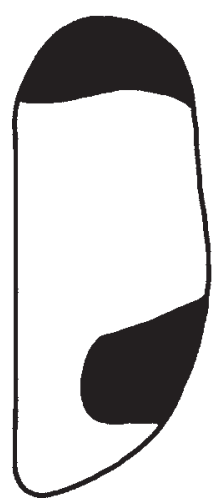

11
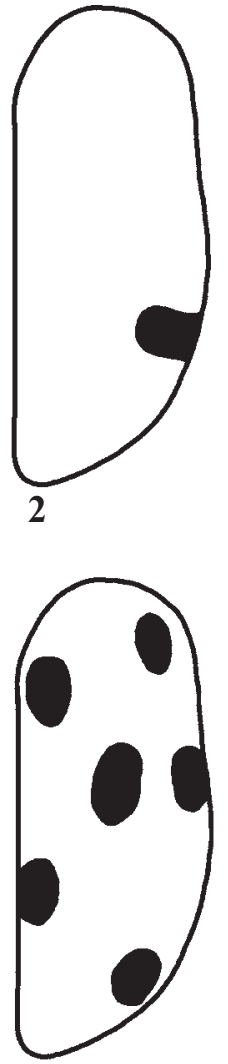

7

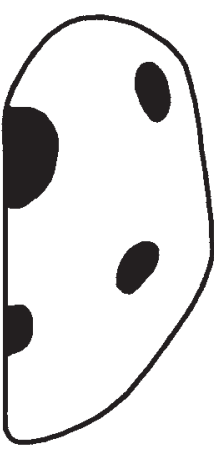

3

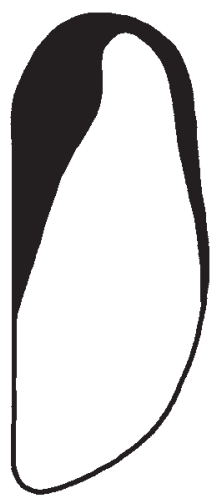

8

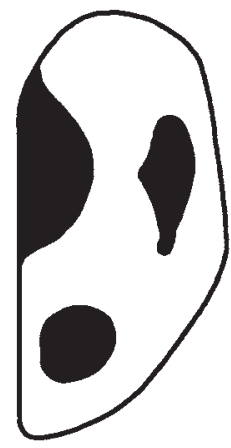

4

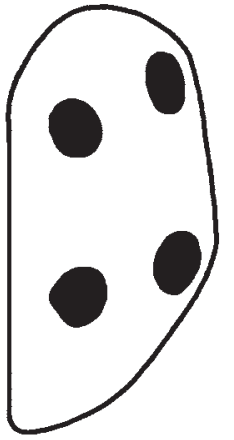

9

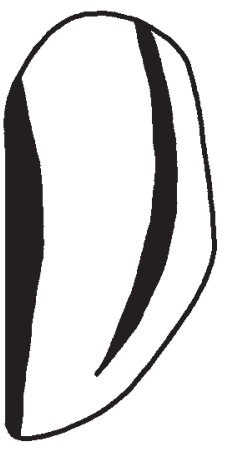

5

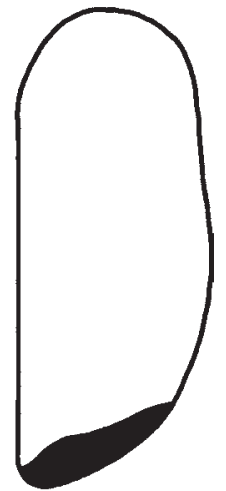

10

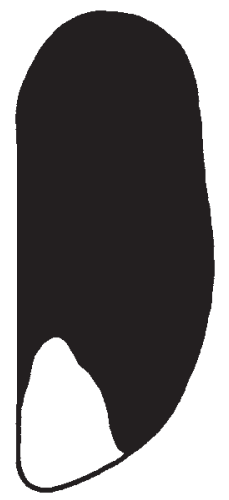

16

Figs 1-16. Elytral pattern:1 - Nonarthra laysi sp.n.; 2 - Epithrix bipunctata sp.n.; 3 - Argopistes borneoensis sp.n.; 4 Chilocoristes schawalleri sp.n.; 5 - Ch. borneoensis sp.n.; 6 - Ch. septemmaculatus, 7 - Amphimela megalayana sp.n.; 8 A. srilankana sp.n.; 9 - Halticorcus bhutanicus sp.n.; 10 - Phygasoma nigripennis sp.n.; 11-12 - Hyphasis wallacei sp.n. (11 - Malaya, 12 - Borneo); 13 - H. srilankana sp.n.; 14 - H. pahangi sp.n.; 15 - Luperomorpha marginicollis sp.n.; 16 - Ivalia nilgiriensis sp.n.

Рис. 1-16. Рисунок надкрылий: 1 - Nonarthra laysi sp.n.; 2 - Epithrix bipunctata sp.n.; 3 - Argopistes borneoensis sp.n.; 4 Chilocoristes schawalleri sp.n.; 5 - Ch. borneoensis sp.n.; 6 - Ch. septemmaculatus, 7 - Amphimela megalayana sp.n.; 8 A. srilankana sp.n.; 9 - Halticorcus bhutanicus sp.n.; 10 - Phygasoma nigripennis sp.n.; 11 - Hyphasis wallacei sp.n. 11 - Malaya, 12 - Borneo); 13 - H. srilankana sp.n.; $14-$ H. pahangi sp.n.; 15 - Luperomorpha marginicollis sp.n.; $16-$ Ivalia nilgiriensis $\mathbf{s p . n .}$ 
rounded, surface impunctate, densely microsculptured. Scutellum triangular, microsculptured. Elytra 1.1 times as wide as long, surface with very feeble and partly confused rows of punctures, interspaces flat, broad, impunctate and microsculptured. Prolongation of hind tibia as long as spur. Aedeagus (Fig. 18) short and broad, with triangular apex, underside with round impression apically. Length of body $3.0 \mathrm{~mm}$.

DIAGNOSIS. Might be compared only with $A$. beccarii Jacoby, 1896, which also has fulvous upperside with large black spot in the middle of elytra, but differs immediately with other elytral pattern and much smaller side.

Chilocoristes schawalleri L.Medvedev, sp.n.

MATERIAL. Holotype,,$: 548$ Nepal: Chitwan Distr., Chitwan N.P.: Souraha, 150 m, 31.V-4.VI.1997, leg. W. Schawaller (SMNS).

DESCRIPTION. Fulvous, basal half of prothorax except margins, large common spoton elytral suture, lateral and preapical spots on each elytron (Fig. 4) black.

Body round, 1.1 times as long as wide, strongly convex. Head impunctate, clypeus with sharp longitudinal ridge, frontal tubercles flat, poorly delimited, microsculptured. Antennae short, proportions of segments are as 12-5-4-4-6-56-6-6-6-8, 4 apical segments thickened, segments $8-10$ as long as wide. Prothorax 2.2 times as wide as long, anterior angles obtuse, posterior angles broadly rounded, posterior margin bisinuate, surface impunctate. Elytra 1.2 times wider than long, with anterolateral angles obtusely angulate, surface with extremely fine punctures and microsculpture, except explanate margins, having rather large, flat and transparent punctures; humeral tubercle absent. Length of body $4.5 \mathrm{~mm}$.

DIAGNOSIS. Near Ch. quinquemaculatus Weise, 1909, which has however body smaller, anterolateral angles of elytra rounded, common sutural spot placed before middle and far removed from basal margin, elytral surface shining and distinctly punctate.

\section{Chilocoristes borneoensis L.Medvedev, sp.n.}

MATERIAL. Holotype,, : E. Malaysia, Borneo, Sabah, Kinabalu Mt., $06^{\circ} 00^{\prime} \mathrm{N}, 116^{\circ} 33^{\prime} \mathrm{E}, 1500 \mathrm{~m}, 27-31$.VII.2009, leg. O. Gorbunov (LM)

DESCRIPTION. Fulvous, antennal segments 3-9, scutellum, sutural and lateral stripes on elytra (Fig. 5) black.

Body ovate short ovate, 1.2 times as long as wide, strongly convex. Head impunctate, impressed along interior margins of eyes, frontal tubercles flat, well delimited, obliquely placed, interantennal space narrow and ridged. Antennae short, reach anterior quarter of elytra, proportions of segments are as 19-7-7-7-7-8-8-8-8-8-12, segments $1-5$ elongate, 6-11 widened, 6-10 about as long as wide. Prothorax 2.3 times as wide as long, lateral margins slightly arcuate, surface shining, very finely punctate. Scutellum small, triangular with rounded apex, finely punctate. Elytra as long as wide, surface finely and confusedly punctate and with a row dividing main surface from explanate margin. Prosternum subquadrate. Length of body $5.1 \mathrm{~mm}$.

DIAGNOSIS. Resemles only Ch. circumdatus L. Medvedev, 2009 from Thailand, which also have black lateral margin on fulvous elytra, but differs immediately in having black sutural stripe and much larger size.

\section{Chilocoristes septemmaculatus Chen, 1934, stat.n.}

Chilocoristes pallidus var. septemmaculatus Chen, 1934.

MATERIAL. $2 \sigma^{\top} \sigma^{\top}$, E. Malaysia, Borneo, Sabah, Sepilok, $05^{\circ} 50^{\prime} \mathrm{N}, 117^{\circ} 50^{\prime} \mathrm{E}, 10-40 \mathrm{~m}, 19-24 . I V .2011$, leg. O. Gorbunov (LM)

REMARK. Both my specimen have 3 large round spots on each elytron (2,1, Fig. 6), while typical Ch. septemmaculatus has common spot on elytral suture and 2 spots on each elytron $(1,1)$. Possibly, my specimens represent a form with divided sutural form.

Aedeagus of Ch. septemmaculatus (Fig. 19) definitely differs from aedeagus Ch. pallidus Baly, 1876 [see Medvedev, 1999].

\section{Amphimela megalayana L.Medvedev, sp.n.}

MATERIAL. Holotype, + : NE India Megalaya, $3 \mathrm{~km}$ E Tura, $25^{\circ} 30^{\prime} \mathrm{N}, 90^{\circ} 14$ E, $1150 \mathrm{~m}, 4 . \mathrm{V} .1999$, leg. Dembicky \& Pachalatko (NHMB).

DESCRIPTION. Fulvous, 7 apical antennal segments, 2 spots on prothorax and 6 spots on elytra $(2,2,1,1)$ black, $4^{\text {the }}$ elytral spot touches suture (Fig. 7).

Body elongate ovate, 1.2 times as long as wide. Head finely punctate and microsculptured, without transverse impression between frons and vertex. Antennae nitidiform, reach anterior quarter of elytra, proportions of segments are as 10-5-5-4-5-56-6-6-6-7, segments 5-10 very feebly triangular. Prothorax twice as wide as long, broadest at base, with lateral margins rounded, anterior angles moderately produced, surface finely and very densely punctate, interspaces narrow and at least partly microsculptured. Scutellum triangular, shining, indistinctly punctate. Elytra 1.4 times as long as wide, parallel-sided with rounded apices, surface with regular rows, more feeble at apical slope, interspaces broad, flat on dorsum and moderately convex on sides, with very fine punctures.

DIAGNOSIS. Near A. picta (Baly, 1877), differs with other pattern on prothorax and elytra and different sculpture of prothorax.

\section{Amphimela laosica L.Medvedev, sp.n.}

MATERIAL. Holotype, O': Laos, Khammouang Prov., Ban Khounkham (Nabin), 18 ${ }^{\circ} 13^{\prime} \mathrm{N}, 104^{\circ} 31^{\prime} \mathrm{E}, 200 \mathrm{~m}, 25 . \mathrm{IV} .2005$, leg. O. Gorbunov (LM)

DESCRIPTION. Fulvous, antennal segments 5-11 black.

Body elongate ovate, 1.5 times as long as wide. Head finely punctate, without frontal tubercles, with arcuate suture dividing frons from interantennal space, but without transverse impression between frons and vertex. Antennae reach anterior third of elytra, proportions of segments are as 7-4-4$4-5-5-5-5-5-5-7$, segments 5-10 slightly triangular. Prothorax 1.9 times as wide as long, broadest in basal third, lateral margins moderately rounded, anterior angles rectangular, not produced, surface finely and very densely punctate, interspaces narrow and microsculptured. Scutellum triangular, shining, impunctate. Elytra 1.25 times as long as wide, broadest near middle, very feebly rounded on sides and broadly rounded at apex, surface with regular rows, very feeble on apical slope, interspaces broad, flat on dorsum and convex more laterally, shining and finely punctate. Aedeagus with triangular apex (Fig. 20). Length of body $2.6 \mathrm{~mm}$.

DIAGNOSIS. Very near to A. flava (Chen, 1933) from Northern Vietnam and South China, which however much larger $(4.0 \mathrm{~mm})$, with transverse furrow between frons and vertex, other proportions of antennal segments $2-4$ and interspaces of elytral rows very convex.

Amphimela srilankana L.Medvedev, sp.n.

MATERIAL. Holotype, ㅇ: Sri Lanka, Kandi, 28.VI.2002, leg. S. Medvedev (LM)

DESCRIPTION. Head fulvous, antennae fulvous with moderately darkened apical segments, prothorax and scutellum black, elytra fulvous with large common black triangle (Fig. 8), underside black, legs fulvous with slightly darkened hind femora.

Body elongate ovate, 1.6 times as long as wide. Head strongly and densely punctate, without frontal tubercles, but 
with transverse impression between frons and vertex. Antennae nitidiform, proportions of segments are as 7-3-3-3-4-4-44-4- (next segments absent). Prothorax almost 2.4 times as wide as long lateral margins very feebly rounded, almost straight, anterior angles produced, surface finely and very densely punctate, with very narrow interspaces. Scutellum triangular, shining, indistinctly punctate. Elytra 1.25 times as long as wide, broadest in anterior third and distinctly narrowed to behind, surface with regular rows, disappearing at apical slope, interspaces flat and broad, densely punctate, but punctures in interspaces are smaller than punctures in rows. Length of body $2.7 \mathrm{~mm}$.

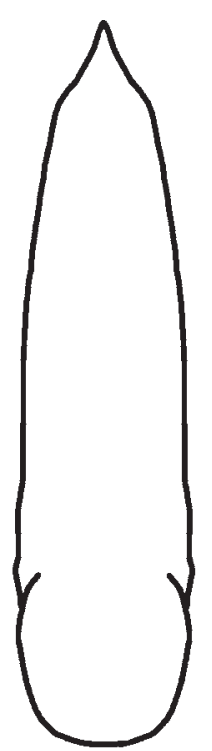

17

22

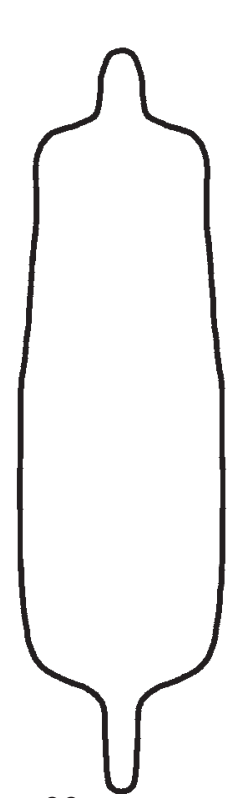

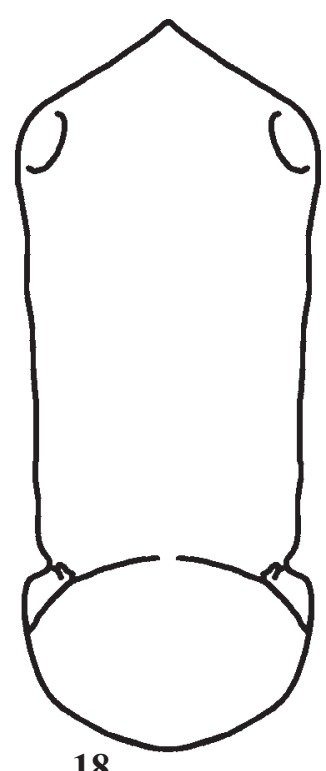

18

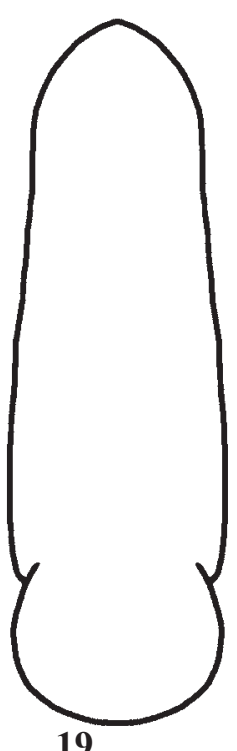

19
DIAGNOSIS. Resembles a little A. apicalis Kimoto, 2000 from Thailand, differs with black prothorax, other elytral pattern and much smaller side.

\section{Halticorcus bhutanicus L.Medvedev, sp.n.}

MATERIAL. Holotype, o : Bhutan, Phuntscholing, Thimphu, $1680 \mathrm{~m}, 22 . V .1972$, expedition 1972 (NHMB).

DESCRIPTION. Fulvous, 5 apical segments, 2 round spots at base of prothorax and 4 spots on each elytron $(2,2$, Fig. 9) black.

Body short ovate, 1.2 times as long as wide. Head impunctate, frons as wide as transverse diameter of eye. Anten-

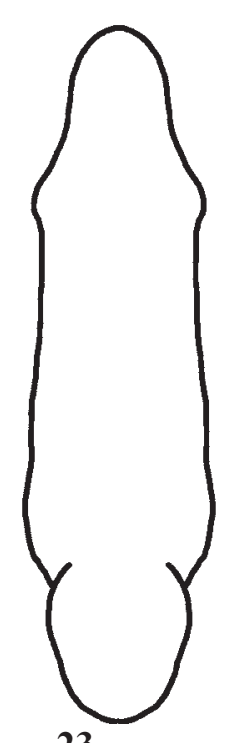

23

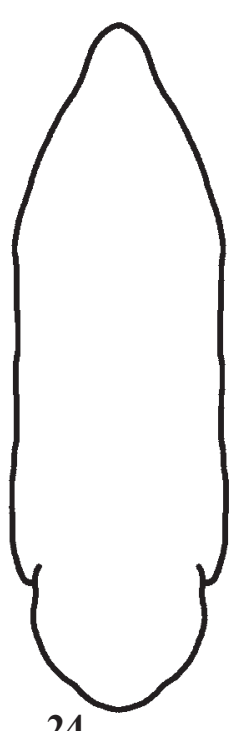

24

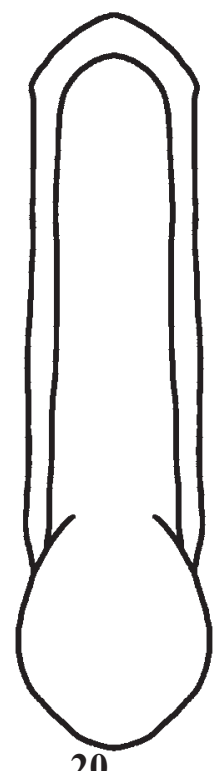

20

21

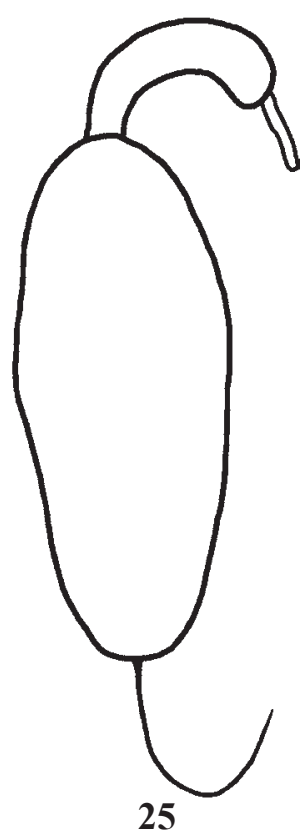

Figs. 17-24. Aedeagus, ventral view: 17 - Epithrix bipunctata sp.n.; 18 - Argopistes borneoensis sp.n.; 19 - Chilocoristes septemmaculatus, 20 - Amphimela laosica sp.n.; 21 - Hyphasis srilankana sp.n.; 22 - H. pahangi sp.n.; 23 — Ivalia sichuana $\mathbf{s p . n . ; ~}$ 24 - Neocrepidodera javana sp.n.; 25 - Ivalia nilgiriensis sp.n., spermatheca.

Рис. 17-24. Эдеагус, вид снизу: 17 - Epithrix bipunctata sp.n.; 18 - Argopistes borneoensis sp.n.; 19 - Chilocoristes septemmaculatus, 20 - Amphimela laosica sp.n.; 21 - Hyphasis srilankana sp.n.; 22 - H. pahangi sp.n.; 23 - Ivalia sichuana sp.n.; 24 - Neocrepidodera javana sp.n.; 25 - Ivalia nilgiriensis sp.n.; сперматека. 
nae reach base of elytra, with 5 apical segments thickened, proportions of segments are as 12-7-6-5-5-5-8-8-8-7-13. Prothorax twice as wide as long, strongly narrowed anteriorly, with side margins almost straight and basal margin strongly produced, surface shining, finely and sparsely punctate. Scutellum small, triangular, shining, indistinctly punctate. Elytra about as long as wide, shining, with regular rows of punctures and broad impunctate interspaces, which are partly slightly convex, partly flat. Length of body $2.8 \mathrm{~mm}$.

DIAGNOSIS. Near H. himalayensis Basu \& Sengupta, 1981, differs in having two round black spots on base of prothorax and quite other elytral pattern, without any common spots on suture, also with other proportions of antennal segments.

\section{Phygasoma nigripennis L.Medvedev, sp.n.}

MATERIAL. Holotype, $q$ : E. Malaysia, Borneo, Sabah, Kinabalu, Mts., $06^{\circ} 00^{\prime} \mathrm{N}, 116^{\circ} 33^{\prime} \mathrm{E}, 1500 \mathrm{~m}, 27-31$.VII.2009, leg. O. Gorbunov (LM).

DESCRIPTION. Body red, antennal segments 5-9 black, scutellum and elytra greenish black (holotype) or metallic green (paratype) with extreme apex narrowly fulvous (Fig. 10), abdominal segments 1 and 2 greenish black.

Head shining, labrum and clypeus impunctate, vertex finely punctate, frontal tubercles ovate, interantennal space broad and moderately convex. Antennae reach humeral tubercles, proportions of segments are as 11-4-5-6-10-10-9-8 $7-7-9$, preapical segments about $2-2.5$ times as long as wide. Prothorax 1.6 times as wide as long, broadest near base, lateral margins slightly arcuate, basal groove biarcuate, with a row of fine punctures, main surface shining and impunctate. Scutellum triangular with rounded apex, microsculptured. Elytra 1.5 times as long as wide, with high humeral tubercle and feeble basal convexity and postbasal impression, surface finely punctate. Length of body $8.4 \mathrm{~mm}$.

DIAGNOSIS. This is the third species of the genus, all they are known from Borneo and might be divided as follow:

1 (2) Upperside deep red with metallic sheen. Length $8.0 \mathrm{~mm}$ Ph. castaneus Chen, 1934

2 (1) Upperside distinctly bicolor. Head and prothorax red.

3 (4) Elytra metallic green with fulvous apical margin, head and prothorax without black spots (type series) or entirely blue, vertex with 2 black spots, prothorax with small black spot in middle (4 specimens in my collection from Kinabalu). Proportions of antennal segments $2-4$ are as 5-10 10. Length $6.8-8.0 \mathrm{~mm}$. Possibly include 2 species......

Ph. borneoense Jacoby, 1898

4 (3) Elytra black with fulvous extreme margin, head and prothorax without black spots. Proportions of antennal segments 2-4 are as 4-5-6. Length $8.4 \mathrm{~mm}$

Ph. nigripennis sp.n.

\section{Laboissierea indica L.Medvedev, sp.n.}

MATERIAL. Holotype, ㅇ: NE India; Meghalaya: $3 \mathrm{~km}$ E Tura, $25^{\circ} 30^{\prime} \mathrm{N}, 90^{\circ} 14^{\prime \prime} \mathrm{E}, 1150 \mathrm{~m}, 18 . \mathrm{IV} .1999$, leg. Dembitsky \& Pacholatko (NHMB). Paratypes: same locality and date, 2 우 (NHMB, LM).

DESCRIPTION. Reddish brown, antennae, underside and legs (with fulvous trochanters) black, pubescense black on antennae, fulvous on upperside.

Body elongate, 2.1 times as long as wide. Labrum and clypeus with a row of small setiferous punctures, frons and vertex strongly punctate, frontal tubercles poorly delimited. Antennae reach middle of elytra, proportions of segments are as 13-3-9-11-11-11-11-10-10-10-15, four apical segments thin, segments $8-10$ about 4 times as long as wide. Prothorax 1.5 times as wide as long, broadest near middle, with rounded lateral margins, surface with well delimited central swelling, divide with longitudinal groove in middle, finely punctate, without microsculpture. Elytra 1.65 times as long as wide, almost parallel-sided, punctures in rows much larger than on prothorax, interspaces very narrow, more or less costate, but without distinct longitudinal ridges. Length of body $9.2-10.4 \mathrm{~mm}$.

DIAGNOSIS. Near L. incostata Pic, 1937 from North Vietnam, differs with black femora, sculpture of prothorax and larger size.

\section{Hyphasis wallacei Baly, 1874}

MATERIAL. W. Malaysia, Selangor, Gohtong Jaya, $3^{\circ} 24^{\prime} \mathrm{N}$, 101 ${ }^{\circ} 46^{\prime}$ E, 1000 m, 25-30.IV.2011, leg. O.Gorbunov, 1 ( ) (LM); E. Malaysia, Borneo, Sabah, Sepilok, $5^{\circ} 52^{\prime} \mathrm{N}, 117^{\circ} 57^{\prime} \mathrm{E}, 10-40 \mathrm{~m}$, 19-24. IV. 2011, leg. O. Gorbunov, 1 ( (LM).

REMARK. This species was described from Malaya and later recorded also on Sumatra and Borneo [Mohamedsaid, 2004]. A specimen from Borneo differs from the nominative form with elytral pattern (Figs 11-12) and might be proved in future as a new subspecies.

\section{Hyphasis srilankana L.Medvedev, sp.n.}

MATERIAL. Holotype, ơ: Sri Lanka, Kandy, 30.VI.2002, leg. S. Medvedev (LM)

DESCRIPTION. Fulvous, elytra at base and on inner half piceous, but this color poorly delimited from fulvous part (Fig. 13).

Body elongate ovate, 1.6 times as long as wide. Head dull, finely microsculptured, frontal tubercles convex, sharply delimited and divided from frons with transverse impression, their surface densely microsculptured; frons a little wider than transverse diameter of eye. Antennae reach apical slope of elytra, proportions of segments are as 9-4-6-7-7-7-76-6-6-8, preapical segments about 4 times as long as wide. Prothorax 2.3 times as wide as long, broadest in middle, side margins rounded, surface without distinct punctures, but microsculptured. Scutellum triangular, shining, impunctate. Elytra 1.2 times as long as wide, very densely punctate, with narrow microsculptured interspaces. Aedeagus (Fig. 21) rather short and thick, with acute triangular apex, evenly convex on underside. Length of body $4.0 \mathrm{~mm}$.

DIAGNOSIS. Near H. limbatipennis Jacoby, 1889, but antennae entirely fulvous and elytral pattern different.

\section{Hyphasis pahangi L.Medvedev, sp.n.}

MATERIAL. Holotype, $\mathrm{O}^{7}$ : W. Malaysia, Pahang, Frasers Hill, $3^{\circ} 43^{\prime} \mathrm{N}, 101^{\circ} 44^{\prime} \mathrm{E}, 1300 \mathrm{~m}, 11-17$. VII.2009, leg. O. Gorbunov (LM).

DESCRIPTION. Head black with fulvous labrum, antennae black with 3 basal segments fulvous, scutellum black, elytra black with transverse spot in middle and very narrow lateral margin fulvous (Fig. 14), underside black, legs fulvous to dark fulvous.

Head dull, microsculptured, with very sparse and fine punctures, frontal tubercles triangular, frons narrower than transverse diameter of eye. Antennae reach apical quarter of elytra, proportions of segments are as 13-7-9-9-10-10-10-99-9-12, preapical segments about 3 times as long as wide. Prothorax twice as wide as long, lateral margins broadest behind middle, but very feebly arcuate, surface shining and impunctate. Elytra twice as long as wide, shining, extremely finely punctate. Segment 1 of anterior and mid tarsi enlarged, elongate. Aedeagus (Fig. 22) with triangular apex. Length of body $3.3 \mathrm{~mm}$.

DIAGNOSIS. Near H. unifasciata Jacoby, 1899 from Malaysia, differs with smaller size and color of elytra, underside and legs, especially with narrow fulvous emargination on sides of elytra. 


\section{Luperomorpha marginicollis L.Medvedev, sp.n.}

MATERIAL. Holotype,, : S-India, Tamil Nadu, Tiruchchirappalli distr.: fra [between] Perambalur e Turaiyur, alle luci [at light], 19.X.1997, leg. A. Sforzi \& L. Bartolozzi (LM).

DESCRIPTION. Head dark fulvous with black labrum, antennae black with 4 basal segments fulvous, prothorax fulvous with black lateral margins, scutellum black, elytra black with white central stripe delimited before apical slope with black band; apical slope white (Fig. 15), epipleurae and legs fulvous, underside piceous with fulvous abdomen.

Body elongate. Head impunctate, but densely microsculptured, frontal tubercles transverse, poorly delimited posteriorly. Antennae reach anterior third of elytra, proportions of segments are as 15-8-7-10-9-10-9-7-7-7-9, preapical segments about 3 times as long as wide. Prothorax 1.45 times as wide as long, broadest near middle, lateral margins moderately arcuate, surface impunctate, finely microsculptured. Scutellum triangular, microsculptured. Elytra 1.7 times as long as wide, finely punctate and densely microsculptured. Length of body $2.6 \mathrm{~mm}$.

DIAGNOSIS. Resembles L. birmanica (Jacoby, 1892), but has quite different elytral pattern. Besides, it differs from all known species of this genus with black lateral margins of prothorax.

\section{Hespera gorbunovi L.Medvedev, sp.n.}

MATERIAL. Holotype,, : E. Malaysia, Borneo, Sabah, Sepilok, $5^{\circ} 52^{\prime} \mathrm{N}, 117^{\circ} 57^{\prime} \mathrm{E}, 10-40 \mathrm{~m}, 19-24 . I V .2011$, leg. O. Gorbunov (LM)

DESCRIPTION. Black, head red with black labrum and antennae, prothorax red, pubescence of upperside light. Head practically not pubescent, shining, very sparsely and finely punctate on vertex, frontal tubercles convex transversely delimited posteriorly, frons a little wider than transverse diameter of eye. Antennae reach apical slope of elytra, proportions of segments are as 10-5-7-10-10-10-10-9-7-7-10, preapical segments about 3 times as long as wide. Prothorax 1.5 times as wide as long, broadest before middle, feebly narrowed anteriorly and more strongly to base, lateral margins feebly arcuate, surface strongly and densely punctate. Scutellum triangular with rounded apex, punctate. Elytra 1.6 times as long as wide, pubescence short and directed backwards, punctures dense and deep, but a little smaller than on prothorax. Length $3.4 \mathrm{~mm}$.

DIAGNOSIS. A single species of this genus known from Borneo is entirely black ( $H$. nigra Chen, 1934). The species in question resembles $H$. ruficollis Chen, 1932 from Indochina, but differs with entirely black antennae and other sculpture of upperside.

\section{Ivalia sichuana L.Medvedev, sp.n.}

MATERIAL. Holotype, $\sigma^{7}$ : China, W. Sichuan (Ganzi Tibet Aut. Pref., Luding Co), W. Erland Shan Pass, $29^{\circ} 51^{\prime}$ N, $102^{\circ} 15^{\prime} \mathrm{E}, 7$ km SSE Luding, 2600 m, 20-29.VI.1999, leg. D.W. Wrase (LM) Paratype: same locality and date, 1 (LM).

DESCRIPTION. Upperside black with feeble metallic luster, antennae fulvous, underside black to piceous, legs fulvous, hind legs more or less piceous. Head impunctate, but very densely microsculptured, vertex with shallow transverse impression. Antennae reach basal quarter of elytra, proportions of segments are as 5-3-2-2-2-2-2-2-3-3-5, preapical segments about as long as wide. Prothorax twice as wide as long, surface impunctate, but very densely microsculptured, with traces of convexity along lateral margin, with a pore in anterior third of lateral margin. Scutellum very small, trian- gular with acute apex. Elytra about as long as wide, strongly convex, without any impressions, surface moderately shining, extremely finely microsculptured. Metasternum saddlelike. Hind of tibia feebly underlate on dorsal margin. Aedeagus - Fig. 23. Length of male $1.7 \mathrm{~mm}$, of female- $1.8 \mathrm{~mm}$.

DIAGNOSIS. Near I. merkli (L. Medvedev, 1998) from Malaysia, which differs with thin antennae, having preapical segments distinctly elongate.

Body 1.3 times as long as wide.

\section{Ivalia nilgiriensis L.Medvedev, sp.n.}

MATERIAL. Holotype, + : India, Tamil Nadu, Nilgiri Ootacamund Dodabetta, west slope, $2750 \mathrm{~m}$, singled near brook, 13.III.1980, leg. G. Topal (LM)

DESCRIPTION. Black with feeble metallic luster, 4 basal antennal segments, apices of elytra (Fig. 16) and legs fulvous to dark fulvous, abdomen fulvous with darkened basal sternite.

Body 1.45 times as long as wide. Head impunctate, finely microsculptured, without impression on vertex. Antennae reach anterior quarter of elytra, proportions of segments are as 8-5-3-2-3-3-5-4-4-4-9, segments 8-10 thickened and feebly transverse. Prothorax twice as wide as long, moderately shining, with fine sparse punctures and microsculptured interspaces, without any convexities on sides. Scutellum very small, triangular. Elytra 1.3 times as long as wide, shining, very finely and sparsely punctate and microsculptured. Metasternum feebly saddle-like. Hind tibia feebly serrate in apical half of dorsal margin. Spermatheca- Fig. 25. Length of body $1.8 \mathrm{~mm}$.

DIAGNOSIS. Differs from all species of the genus with elongate body and color of upperside.

\section{Neocrepidodera javana L.Medvedev, sp.n.}

MATERIAL. Holotype, ơ: Java (LM). Paratypes: same locality, $2 \sigma^{7} \sigma^{7}, 1$ ㅇ (LM).

DESCRIPTION. Fulvous, apical antennal segments sometimes slightly darkened, elytra (except epipleurae) piceous or almost black.

Body elongate. Head impunctate, frontal tubercles almost indistinct, interantennal space with moderately broad convexity connected with clypeus. Antennae reach anterior quarter of elytra, proportions of segments are as 11-7-5-6-66-6-7-7-7-12, preapical segments almost twice as long as wide. Prothorax 1.8 times as wide as long, broadest in anterior third, lateral margin arcuate, transverse basal groove shallow, surface shining, finely and sparsely punctate, with more dense punctures behind basal groove. Elytra elongate ovate, 1.45 times as long as wide, elytral rows rather feeble, more or less confused in sutural area. Aedeagus (Fig. 24) with acute triangular apex. Length of males $2.2-2.3 \mathrm{~mm}$, of female 2.5 $\mathrm{mm}$.

DIAGNOSIS. Near N. sumatrana (Jacoby, 1894), differs with dark color of elytra.

\section{References}

Medvedev L.N. 1999. To the knowledge of Oriental Alticinae (Coleoptera, Chrysomelidae). Genera Euphitrea Baly, 1875, Chilocoristes Weise, 1895, Pentamesa Harold, 1876, and Maulika Basu \& Sengupta, 1980 // Russian Entomological Journal. Vol.7 (for 1998). Nos3-4. P.147-156.

Mohamedsaid M S. 2004. Catalogue of the Malaysian Chrysomelidae (Insecta: Coleoptera). Sofia: Pensoft. 239 pp. 